SCJR 16, no. 1 (2021): 1-3

\title{
Tim Dowley Defying the Holocaust: Ten Courageous Christians who Supported Jews
}

\author{
(London: Society for Promoting Christian Knowledge, 2020), \\ paperback, $x v+243$ pp.
}

\section{REBECCA CARTER-CHAND}

rcarter-chand@ushmm.org

United States Holocaust Memorial Museum, Washington, DC 20024

* The views expressed are those of the author and do not represent those of the United States Holocaust Memorial Museum.

Stories of rescue during the Holocaust are compelling because they present a glimmer of goodness amongst widespread evil. Often, they are employed with a didactic purpose to inspire ethical behavior. For Jewish survivors in the postwar era, acknowledging rescuers was a way to reaffirm goodness in the world, something "for which it was worth surviving," as Primo Levi put it. But at their worst, rescue stories can erase Jewish agency, obscure Jewish experience, and gloss over historical contingency, emphasizing instead the rescuers' altruism and courage. Works on "Christian rescuers" can further distort the history and do a disserve to contemporary Jewish-Christian relations by presenting them as counterweights to the complicity of many Christian institutions, communities, and individuals, as though one cancels out the other. Tim Dowley's recent book Defying the Holocaust (from the publishing arm of the Society for Promoting Christian Knowledge) falls into this sub-genre of Christian historical writing. Through a narrative-driven compilation of rescue stories, the author hopes to illustrate "the diversity, courage, and determination" of the rescuers (2). Unfortunately, by defining "Christian" in quite narrow terms, the book misses an opportunity to add to our understanding of Christianity and the Holocaust.

Dowley begins with a brief introduction, reminding readers that the vast majority of people did not rescue Jews during the Holocaust, that not all rescuers were Christian, and that some "Christian" rescuers did not articulate "Christian" reasons for their actions. He does not elaborate on Christian complicity but he does stress that rescuers were the rare exception. Further complicating the ethics of rescue, he writes that some Christian rescuers like Marion Pritchard later admitted to breaking most of the Ten Commandments while valiantly saving Jews. Unfortunately, these 
points are not elaborated upon, nor does the author engage the vast scholarly literature on rescue. Instead Dowley presents ten portraits of individuals whom he believes rescued Jews for "explicitly Christian reasons" (6). Some felt a special kinship with Jews or responded to biblical teachings on compassion, love, and justice.

In addition to some well-known and celebrated figures like Corrie ten Boom and her Dutch Reformed network, Dowley presents some lesser-known rescuers such as Maria Stobtsova, an aristocratic Russian émigré in Paris who became an Orthodox nun at the age of 40. Stobtsova spent the war years working with the French resistance in assisting and sheltering Jews. Dom Bruno (born Henri Reynders) was a Belgian Benedictine monk who began the war as a military chaplain during the German invasion of Belgium. After sustaining an injury, he spent the remainder of the war coordinating clandestine shelter for Jewish children. Other figures are well known in their home countries but may be new to English-speaking audiences. Stanisława Leszczyńska was a Polish midwife who was arrested in 1943, along with her husband and children, for forging documents for Jews. She spent two years as a prisoner and midwife in Auschwitz, where she took great personal risk attempting to deliver babies safely. For these efforts she is currently an official candidate for sainthood by the Catholic Church.

It is helpful to consider what function these stories (and similar collections) serve. One function is clearly didactic: it promotes the idea that deep personal piety will result in the moral fortitude necessary to help others in need, even at great personal risk. Another unstated function is to give shape to a shared identity of devout Christian rescuers, an identity that is juxtaposed not so much with other religious identities but with secular Europeans and marginally-practicing Christians. After all, during the Holocaust most of Europe was Christian; over 95\% of Germans belonged to a Christian church. But these are not the Christians Dowley is interested in exploring; his is a narrower category. At the same time, his definition is also broader because it is not bound by national borders, ethnic identities, denominational bodies, or ecclesiastical rank. There are clergy and laity, men and women, Protestants, Catholics, and Orthodox from diverse parts of Europe represented in this volume. The fact that it cuts across these distinctions is praiseworthy, especially given how historical writing, much to its detriment, is often done within, not across, these categories.

An unexplored thread that connects most of the people profiled in this book is their support for missions to Jews. Many Christians working in these settings fiercely opposed the antisemitism of fascists and showed empathy and solidarity with Jews, but they also had connections to organizations or churches that specifically sought to convert Jews to Christianity. In several chapters Dowley also discusses baptisms of Jews, the issuance of baptismal certificates, and the instruction of Jews in Christian teaching and practice (which could help Jews pass as Christians, though this could of course serve other goals). Dowley makes inferences about those Jews who "genuinely wanted to become Christians" (32), as well 
as the motivations of individual clergy who undertook this work. The complexities-especially where children were concerned - are not addressed. Here is where including Jewish perspectives could add nuance and illumination to these stories.

Despite its compelling story-telling and diverse set of remarkable individuals and wartime settings, this book would have benefited from more engagement with the relevant scholarship to better explain the complicated entanglements of Jews and Christians in 1940s Europe. 